\title{
EVALUASI NILAI DAYA LELEH DAN NILAI ORGANOLEPTIK ESKRIM BERBAHAN DASAR SUSU SAPI KOMBINASI DENGAN KACANG MERAH PADA LEVEL YANG BERBEDA
}

\author{
Irmayani ${ }^{1}$, Nurheda $^{1}$, Intan Dwi Novieta ${ }^{1}$, Nurfatima ${ }^{1}$ \\ ${ }^{1}$ Fakultas Pertanian Peternakan dan Perikanan Universitas Muhammadiyah Parepare \\ E-mail : irmaumpar06@gmail.com
}

\begin{abstract}
ABSTRAK
Es krim memiliki cita rasa yang beragam dan nilai gizi yang tinggi sehingga digemari oleh semua kalangan masyarakat mulai dari anak-anak, dewasa dan orang tua. Bahan utama eksrim adalah susu sapi dengan penambahan biji kacang merah memberikan nilai rasa tersendiri bagi eskrim. Penelitian ini bertujuan mengetahui kandungan nilai organoleptic dan nilai daya leleh eskrim dengan penambahan kacang merah dengan level yang berbeda. Penelitian menggunakan metode percobaan dengan rancangan acak lengkap (RAL) dengan 4 taraf perlakuan $\mathrm{Ko}$ (sebagai control), $\mathrm{K}_{1}(10 \%), \mathrm{K}_{2}(20 \%), \mathrm{K}_{3}(30 \%)$. Setiap perlakuan diulang sebanyak 4 kali. Hasil penelitian menunjukkan Uji organoleptic (Warna, rasa, tekstur dan aroma) berpengaruh sangat nyata $(P<0,01)$ sedangkan untuk daya leleh eskrim berbahan dasar susu sapi kombinasi dengan kacang merah bepengaruh sangat nyata $(P<0,01)$ terhadap kecepatan daya leleh es krim. Kesimpulan dari penelitian adalah Persentase kacang merah(phaseoulus vulgaris $L$ ) pada es krim berpengaruh pada karakteristik organoleptik meliputi rasa, aroma, warna, dan tekstur, persentase kacang merah (Phaseoulus vulgaris $L$ ) yang paling baik digunakan dalam es krim yaitu persentase $10 \%$, Semakin tinggi presentase penambahan kacang merah (Phaseoulus vulgaris $L$ ) dalam pembuatan es krim, maka semakin rendah daya leleh es krim.
\end{abstract}

Kata Kunci : Es krim; kacang merah; nilai organoleptic dan daya leleh

\begin{abstract}
Ice cream has a variety of flavors and high nutritional value, so it is popular with all people, from children, adults and the elderly. The main ingredient for ice cream is cow's milk with the addition of red bean seeds which gives the ice cream its own flavor. This study aims to determine the content of the organoleptic value and the melting power of the ice cream with the addition of red beans with different levels. The study used a completely randomized design experiment (CRD) with 4 treatment levels of Ko (as control), K1, K2, K3. Each treatment was repeated 4 times. The results showed that the organoleptic test (color, taste, texture and aroma) had a very significant effect $(P<0.01)$, while the melting power of ice cream made from cow's milk combined with red beans had a very significant effect $(P<0.01)$ on the power speed. melted ice cream. The conclusion of the study is the percentage of red beans (phaseoulus vulgaris $L$ ) in ice cream affects the organoleptic characteristics including taste, aroma, color, and texture, the percentage of red beans (Phaseoulus vulgaris $L$ ) which is best used in ice cream is a percentage of $10 \%$. The higher the percentage of the addition of kidney beans (Phaseoulus vulgaris $L$ ) in making ice cream, the lower the melting power of the ice cream.
\end{abstract}

Keywords: Ice cream; Red beans; organoleptic value and melting power

\section{PENDAHULUAN}

Susu merupakan campuran kompleks berbagai senyawa yang terlarut atau terdispersi didalam air. Kandungan gizi susu dianggap baik karena mempunyai proporsi yang seimbang dan mudah dicerna, sehingga dalam jumlah tertentu susu dapat memenuhi akan zat gizi bagi tubuh (Legowo dkk 2009). Tingginya kandungan gizi pada susu membuat susu tersebut menjadi 
sumber makanan bagi mikroba yang menyebabkan susu mudah mengalami kerusakan (perishable) olek karena itu, agar susu memiliki daya simpan yang lebih lama dibutuhkan suatu pengolahan, salah satunya adalah es krim.

Menurut SNI (1995) es krim adalah jenis makanan semi padat yang dibuat dengan cara pembekuan tepung es krim atau dari campuran susu, lemak maupun nabati, gula, dengan atau tanpa bahan makanan lain dan bahan tambahan makanan yang diizinkan. Es krim memiliki cita rasa yang beragam dan nilai gizi yang tinggi sehingga digemari oleh semua kalangan masyarakat mulai dari anak-anak, dewasa dan orang tua. Selain itu es krim memiliki harga yang terjangkau oleh semua kalangan masyarakat.

Pada zaman sekarang ini terdapat banyak jenis es krim yang dipasarkan dengan aneka warna dan rasa tetapi tidak menjamin dari segi keamanan pangan. Berbagai produk es krim komersial sering menggunakan pewarna sintetik dan perasa yang dapat memberikan efek karsinogenik bagi kesehatan konsumen. Hal inilah yang menjadi alasan untuk mencari alternative bahan tambahan pangan lainnya yang memiliki nilai nutrisi yang tinggi salah satunya adalah kacang merah..

Kacang merah tergolong makan nabati kelompok kacang polong (legume); satu keluarga dengan kacang hijau, kacang kedelai, kacang tolo, dan kacang uci. Ada beberapa jenis kacang merah diantaranya adalah red bean, kacang adzuki (kacang merah kecil), dan kidney bean (kacang merah besar) (Uswatun 2011). Kacang merah (Phaseolus vulgaris L) merupakan tanaman sumber protein baik, dengan kandungan protein yang baik, dengan kandungan protein sekitar 23,1 \% (Depkes, 2018). Selain itu merupakan sumber karbohidrat kompleks, serat, vitamin B, folasin, tiamin, kalsium, fosfor dan zat besi. Folasin adala zat gizi esensial yang mampu mengurangi resiko kerusakan pada pembuluh darah. Sejauh ini pemanfaatan kacang merah masih terbatas dalam produksi makanan, yakni berupa sup kacang merah, kue-kue atau sebagai campuran sayur dan lauk pauk seperti rendang. Untuk mengembangkan keanekaragaman dan pemanfaatan kacang merah, maka dilakukan dengan cara memamfaatkan kacang merah dalam pembuatan es krim.

Kacang merah mengandung banyak zat nutrisi yang dibutuhkan tubuh manusia, sehingga sangat cocok untuk digunakan sebagai bahan tambahan dalam produk pangan contohnya es krim. Es krim merupakan produk olahan yang sangat digemari oleh semua kalangan masyarakat. Penggunaan kacang merah pada konsentrasi tertentu akan mempengaruhi kualitas es krim sehingga penelitian ini dilakukan untuk mengetahui pengaruh penambahan kacang merah terhadap kualitas es krim ditinjau dari daya leleh dan mutu organoleptic (warna, rasa, tekstur dan aroma).

\section{MATERI DAN METODE}

\section{Materi Penelitian}

Penelitian ini dilaksanakan di Laboratorium Fakultas Pertanian, Peternakan dan Perikanan Universitas Muhammadiyah Parepare pada bulan juli sampai agustus 2018.

Bahan yang digunakan dalam penelitian ini adalah : kacang merah, gula pasir, susu UHT, susu kental manis, kuning telur dan air.

Alat yang digunakan dalam penelitian ini adalah : kompor gas, timbangan digital, penghalus (blender), balloonwisk (stainless), spatula (plastic), handmixer, freezer, wadah es krim.

\section{Metode Penelitian}

Penelitian ini menggunakan Rancangan Acak Lengkap (RAL) data yang diperoleh dianalisis dengan analisis anova. Penelitian terdiri dari 4 perlakuan (Ko, K1, K2 dan K3) dan ulangan sebanyak 4 kali dan jika penelitian ada yang berpengaruh nyata dilanjutkan dengan uji Duncan. Penelitian ini menggunakan uji mutu hedonic yang dilakukan oleh 15 panelis semi terlatih terdiri dari laki-laki dan perempuan.

Vol. $2(2): 125-133$ 
Tahapan penelitian terdiri dari : pembuatan es krim kacang merah, analisis uji organoleptic dan menghitung kecepatan daya leleh.

Tahapan pembuatan es krim kacang merah sebagai berikut :

Pembuatan sari kacang merah

Kacang merah dicuci dengan air bersih, lalu direndam selama 10 jam kemudian direbus sampai masak dan dihaluskan dengan blender.

Pembuatan Es krim Kacang merah

Susu dipanaskan, telur yang sudah dikocok dan gula pasir dengan suhu $80^{\circ} \mathrm{C}$ sambil diaduk sampai mendidih setelah itu membagi 4 sesuai dengan perlakuan . mencampurkan sari kacang merah (sesuai perlakuan dimana K0 : tanpa perlakuan, $\mathrm{K} 1$ : $10 \%$, K3, $20 \%$ dan $\mathrm{K} 330 \%$ ). Adonan es krim yang masih dalam keadaan hangat kemudian dihomogenisasi dengan menggunakan mixer selama 15 menit. Setelah itu di-aging (dimatangkan) pada suhu $4^{\circ} \mathrm{C}$ selama 8 jam. Lalu campuran es krim di simpan di wadah plastik dan langsung dibekukan dalam freezer selama 24 jam. Es krim siap disajikan di hadapan panelis.

Prosedur pengujian variabel yang pertama uji organoleptik di laksanakan menggunakan hedonik test dengan 15 mahasiswa yaitu 7 laki-laki dan 8 perempuan. Penilaian meliputi penilaian keadaan kesukaan penelis terhadap produk es krim kacang merah yang terdiri dari 4 kriteria yaitu warna, aroma, rasa, dan tekstur sedangkan Daya leleh dinyatakan dalam menit untuk melihat ketahanan es krim terhadap pelelehan pada saat dihidangkan disuhu $20^{\circ-} \mathrm{C}$ dengan menggunakan stopwatch dan dilakukan secara visual.

\section{HASIL DAN PEMBAHASAN}

\section{Uji organoleptic}

\section{a. Warna}

Hasil penelitian menunjukkan nilai rata-rata tingkat uji organoleptik (warna) es krim dengan penambahan kacang merah dengan level yang berbeda disajikan pada gambar 1.

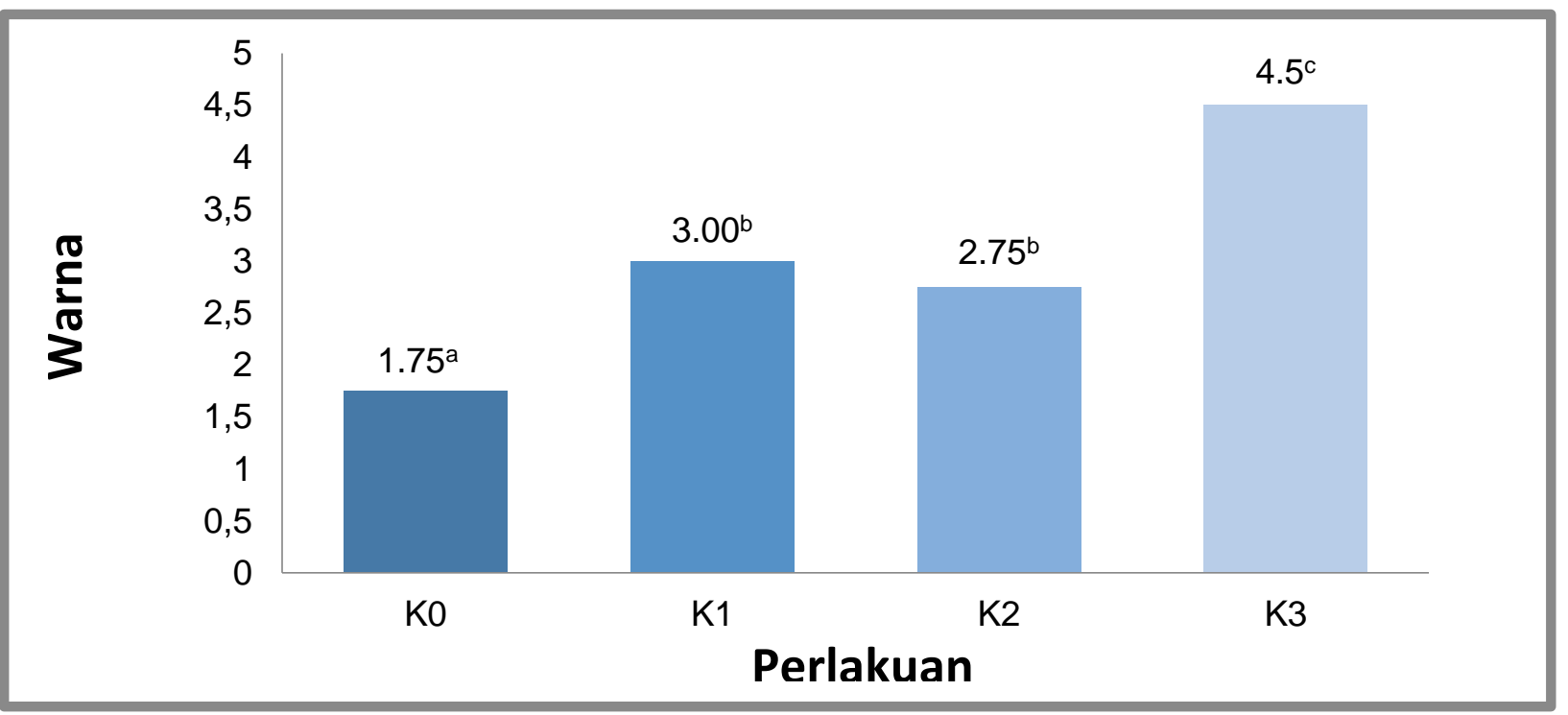

Gambar 1. Nilai rata-rata tingkat uji organoleptic (warna) es krim

Keterangan : Superskrip yang berbeda pada diagram menunjukkan berpengaruh sangat nyata $(\mathrm{P}<0,01)$ terhadap uji organoleptic pada warna es krim kacang merah 
Dari hasi pengamatan untuk sifat organoleptic es krim dengan penambahan kacang merah terhadap warna es krim dapat dilihat pada Gambar 1. Data menunjukkan bahwa tingkat kesukaan panelis terhadap warna es krim dengan penambahan kacang merah pada level yang berbeda memberikan kisaran rataan 1,75 (kuning) sampai 4,5 (coklat). Berdasarkan hasil sidik ragam menunjukkan bahwa level penambahan kacang merah dengan perlakuan $10-30 \%$ berpengaruh sangat nyata $(P<0,01)$ terhadap aroma es krim dibandingkan dengan tidak ditambahkan kacang merah. Hasil uji lanjut Duncan menunjukkan $\mathrm{K}_{3}$ berbedah nyata dengan $\mathrm{K}_{0}$, $\mathrm{K}_{1}$, dan $\mathrm{K}_{2}$.

Mutu bahan makanan ditentukan oleh berbagai faktor salah satunya faktor visual. Faktor visual terpenting yang dapat menentukan penilaian konsumen dan memberikan pengaruh yang besar adalah warna. Data hasil uji organoleptic warna es krim menunjukkan bahwa penambahan kacang merah pada level $30 \%$ lebih disukai panelis, dimana pada level tersebut kandungan kacang merahnya lebih tinggi. Hal ini disebabkan karena kacang merah memiliki dominan warna coklat sehingga mempengaruhi warna pada akhir makanan. Hal ini sesuai dengan pendapat Lanusu dkk (2017) yang menyatakan bahwa warna merupakan kesan pertama dari suatu produk yang menentukan penerimaan atau penolakan panelis terhadap produk tersebut.

\section{b. Rasa}

Hasil penelitian menunjukkan nilai rata-rata tingkat uji organoleptik (rasa) es krim dengan penambahan kacang merah dengan level yang berbeda disajikan pada gambar 2 .

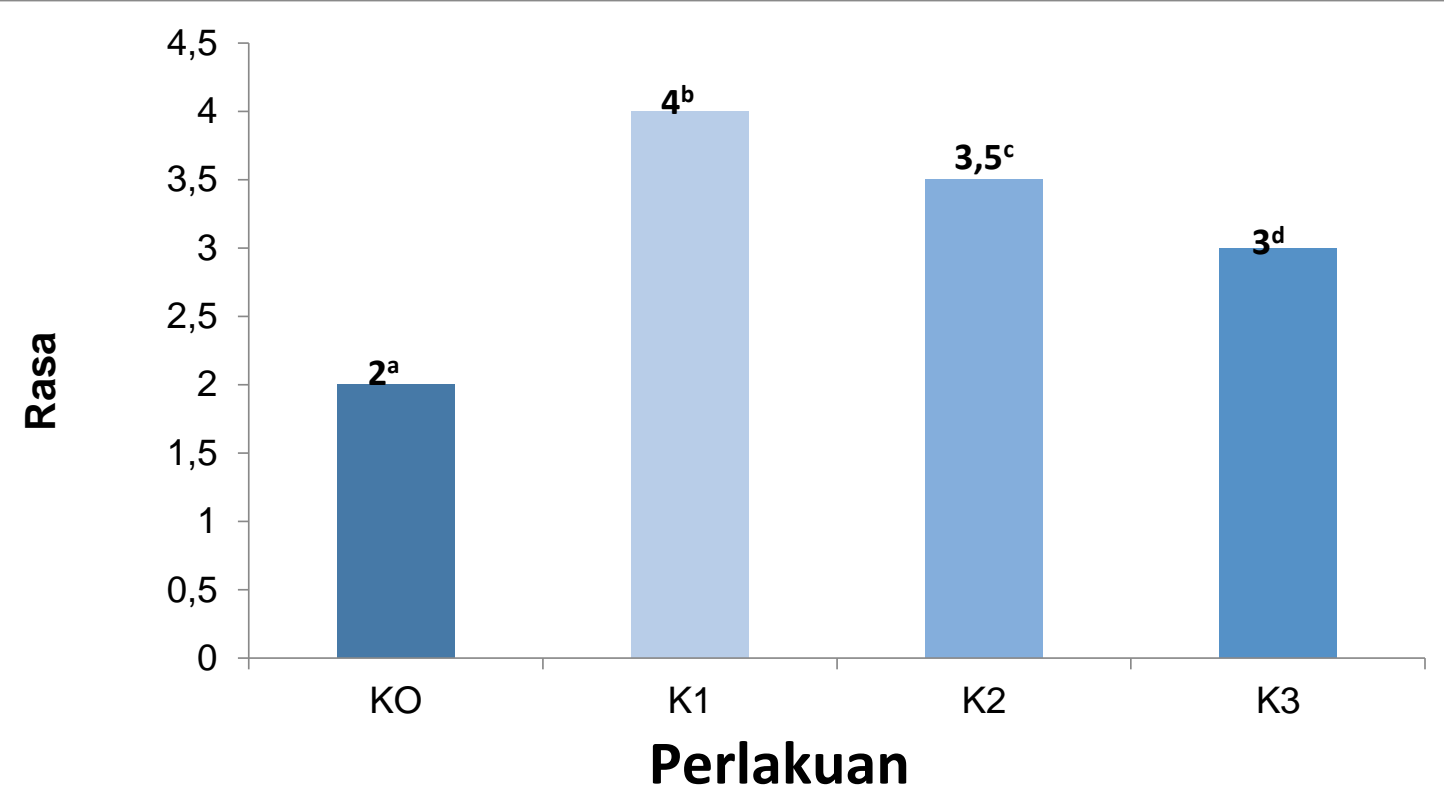

Gambar 2. Nilai rata-rata tingkat uji organoleptik (rasa) es es krim

Keterangan : Superskrip yang berbeda pada diagram menunjukkan berpengaruh sangat nyata $(\mathrm{P}<0,01)$ terhadap uji organoleptic pada rasa es krim kacang merah.

Dari hasi pengamatan untuk sifat organoleptik es krim dengan penambahan kacang merah terhadap rasa es krim dapat dilihat pada gambar 2. Data tersebut menunjukkan bahwa panelis lebih banyak menyukai es krim dengan penambahan $10 \%$ kacang merah dikarenakan rasa es krim tidak berubah sehingga tetap disukai oleh panelis sedangkan pada penambahan kacang 
merah pada level $20 \%$ dan $30 \%$ rasa es krim berubah sehingga kurang diminati oleh panelis. Hal ini dikarenakan pada level $20 \%$ dan $30 \%$ rasa es krim mulai berubah karena domginan rasa kacang merah. Hal ini sesuai dengan pendapat Nurlita (2017) yang menyatakan bahwa rasa merupakan faktor paling penting dalam menentukan keputusan bagi konsumen untuk menerima atau menolak suatu makanan atau produk pangan

Berdasarkan hasil sidik ragam menunjukkan bahwa level penambahan kacang merah dengan perlakuan $10-30 \%$ berpengaruh sangat nyata $(P<0,01)$ terhadap aroma es krim dibandingkan dengan tidak ditambahkan kacang merah. Hasil uji lanjut Duncan menunjukkan $\mathrm{K}_{1}$ berbedah nyata dengan $\mathrm{K}_{0}, \mathrm{~K}_{2}$, dan $\mathrm{K}_{3}$. Rasa pada bahan pangan merupakan kombinasi antara cita rasa dan bau. Produsen menggunakan perasa (plavor) tertentu untuk menghasilkan cita rasa yang diinginkan konsumen. Rasa sangat mempengaruhi kesukaan konsumen terhadap es krim bahkan dapat dikatakan faktor penentu utama (Thompson et al., 2009)

\section{c. Tekstur}

Hasil penelitian menunjukkan nilai rata-rata tingkat uji organoleptik (tekstur) es krim dengan penambahan kacang merah dengan level yang berbeda disajikan pada gambar 3.

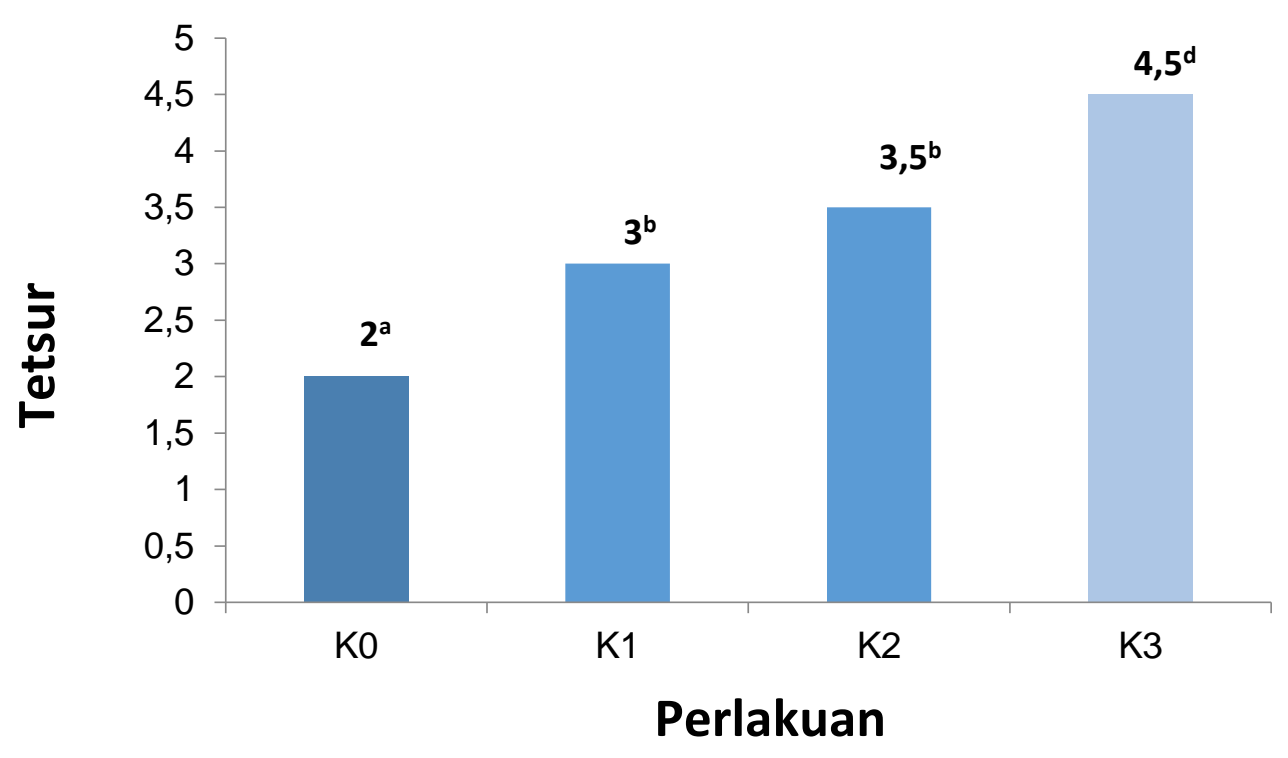

Gambar 3. Nilai rata-rata tingkat uji organoleptic (tekstur) es krim

Keterangan : Superskrip yang berbeda pada diagram menunjukkan berpengaruh sangat nyata $(\mathrm{P}<0,01)$ terhadap uji organoleptic pada tekstur es krim kacang merah.

Dari hasi pengamatan untuk sifat organoleptik es krim dengan penambahan kacang merah terhadap tekstur es krim dapat dilihat pada gambar 3. Data menunjukkan bahwa tingkat kesukaan panelis terhadap tekstur es krim dengan penambahan kacang merah pada level yang berbeda memberikan kisaran rataan 2 (kasar) sampai 4,5 (sangat lembut). Berdasarkan hasil sidik ragam menunjukkan bahwa level penambahan kacang merah dengan perlakuan $10-30 \%$ berpengaruh sangat nyata $(P<0,01)$ terhadap tekstur es krim dibandingkan dengan tidak ditambahkan kacang merah. Hasil uji lanjut Duncan menunjukkan $\mathrm{K}_{3}$ berbedah nyata dengan $\mathrm{K}_{0}$, $\mathrm{K}_{1}$, dan $\mathrm{K}_{2}$. 
Tekstur merupakan ciri suatu bahan sebagai akibat perpaduan dari beberapa sifat fisik yang meliputi ukuran, bentuk, jumlah dan unsur-unsur pembentukan bahan yang dapat dirasakan oleh indera peraba dan perasa, termasuk indera mulut dan penglihatan (Midayanto dan Yuwono, 2014). Data hasil uji organoleptic tekstur es krim menunjukkan bahwa penambahan kacang merah pada level $30 \%$ lebih disukai panelis, dimana pada level tersebut kandungan kacang merahnya lebih tinggi. Penambahan kacang merah membuat es krim lebih lembut yang dipengaruhi oleh padatan yang terkandung dalam adonan es krim, dimana padatan tersebut berasal dari karbohidrat, padatan susu tanpa lemak dan protein. Hal ini sesuai dengan Uswatun (2011) bahwa unsur karbohidrat pada kacang merah pada proses pembuatan es krim berfungsi meningkatkan tekstur dan menstabilkan daya ikat air yang berpengaruh pada kekentalan dan tekstur es krim yang lembut.

\section{Aroma}

Hasil penelitian menunjukkan nilai rata-rata tingkat uji organoleptik terhadap aroma es krim dengan penambahan kacang merah dengan level yang berbeda disajikan pada gambar 4 .

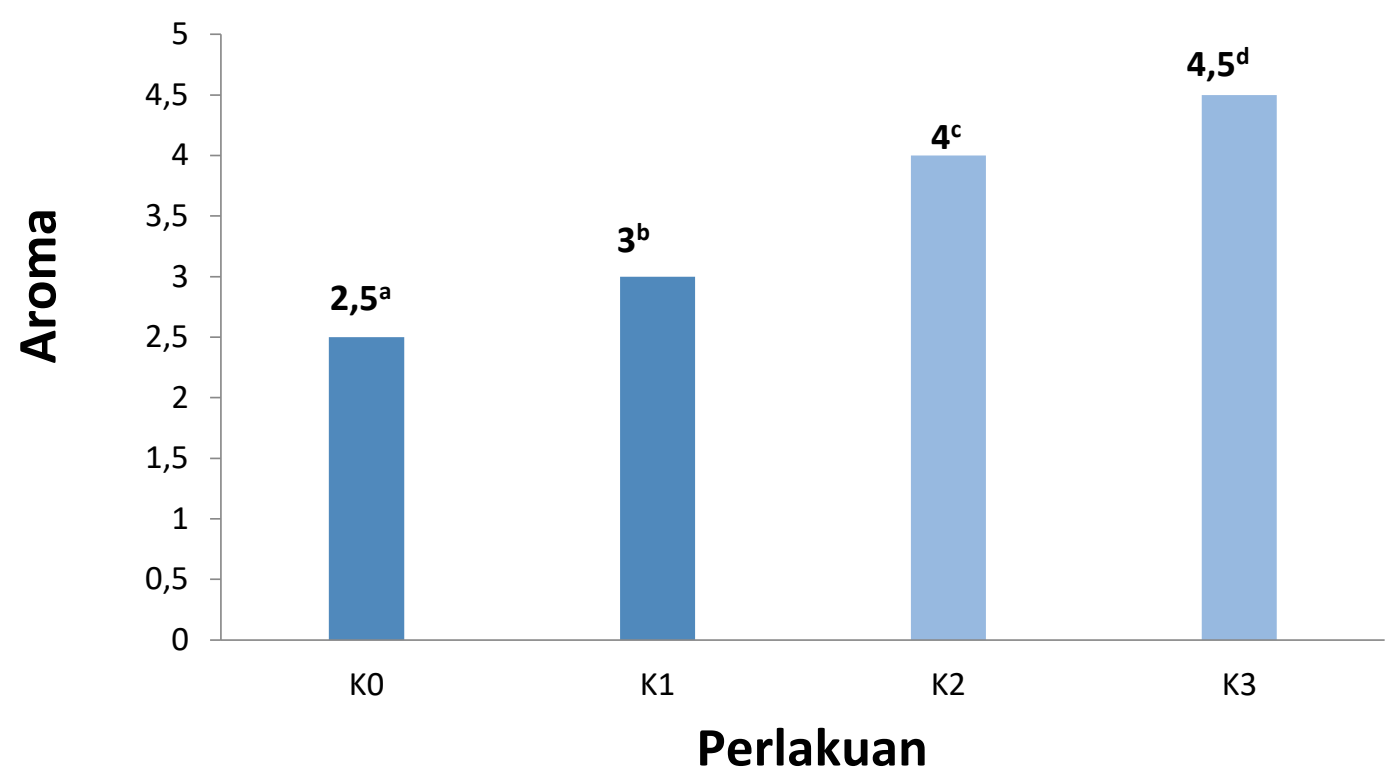

Gambar 4. Nilai rata-rata tingkat uji organoleptik (aroma) es krim Keterangan : Superskrip yang berbeda pada diagram menunjukkan berpengaruh sangat nyata $(\mathrm{P}<0,01)$ terhadap uji organoleptic pada aroma es krim kacang merah.

Dari hasi pengamatan untuk sifat organoleptic es krim dengan penambahan kacang merah terhadap aroma es krim dapat dilihat pada gambar 4. Data menunjukkan bahwa tingkat kesukaan panelis terhadap aroma es krim dengan penambahan kacang merah pada level yang berbeda memberikan kisaran rataan 2,5 (beraroma susu) sampai 4,5 (sangat beraroma kacang merah)

Berdasarkan hasil sidik ragam menunjukkan bahwa level penambahan kacang merah dengan perlakuan $10-30 \%$ berpengaruh sangat nyata $(P<0,01)$ terhadap aroma es krim dibandingkan dengan tidak ditambahkan kacang merah. Hasil uji lanjut Duncan menunjukkan $\mathrm{K}_{3}$ berbedah nyata dengan $\mathrm{K}_{0}, \mathrm{~K}_{1}$, dan $\mathrm{K}_{2}$.

Kandungan senyawa pada suatu bahan terlarut dalam air dan lemak mampu menghasilkan aroma. Indera penciuman berfungsi mendeteksi aroma yang menguap bersama

Vol. 2 (2) : 125-133 
senyawa diudara. Aroma susu umumnya mencirikan aroma khas yang dapat berubah bila terkena senyawa atau benda tertentu (Nurwantoro, 2009)

Data hasil uji organoleptic aroma es krim menunjukkan bahwa penambahan kacang merah pada level 30 \% lebih disukai panelis, dimana pada level tersebut kandungan kacang merahnya lebih tinggi. Hal ini disebabkan karena kacang merah memiliki aroma agak langu hal ini sesuai dengan pendapat Verawati (2015) yang menyatakan bahwa kacang merah mengandung enzim lipoksigenase yang menghasilkan beany flavor atau aroma langu.

\section{Daya Leleh}

Hasil penelitian menunjukkan nilai rata-rata tingkat nilai daya leleh es krim berbahan dasar susu sapi dengan kombinasi kacang merah dengan level yang berbeda yang disajikan pada gambar 5.

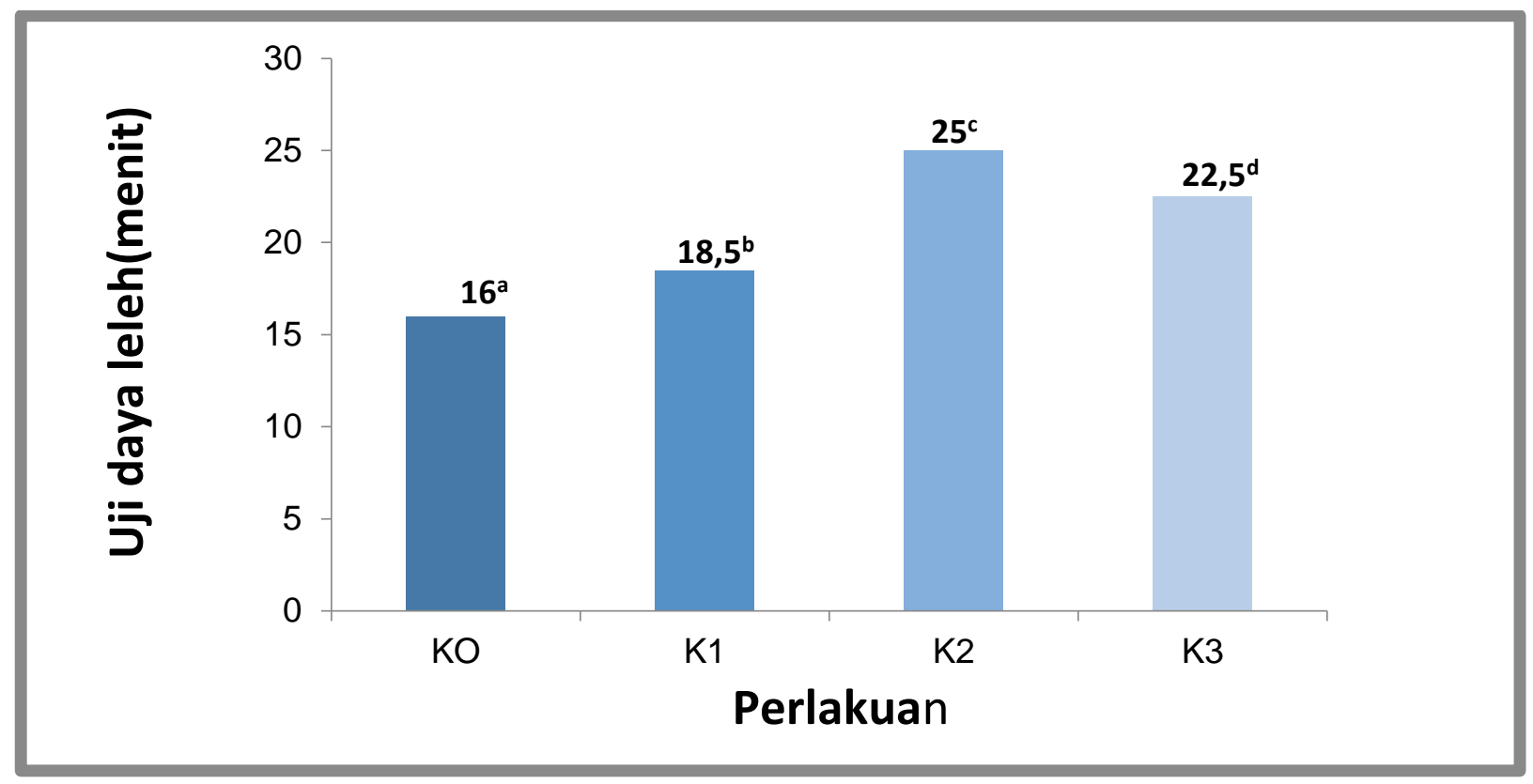

Gambar 5. Nilai rata-rata tingkat nilai daya leleh es krim

Keterangan : Superskrip yang berbeda pada diagram menunjukkan berpengaruh sangat nyata $(P<0,01)$ terhadap nilai daya leleh es krim kacang merah.

Dari hasi pengamatan untuk nilai daya leleh es krim dengan penambahan kacang merah dapat dilihat pada gambar 5. Data menunjukkan bahwa level $20 \%$ yang terbaik karena memiliki waktu leleh lebih lama yaitu 25 menit, sedangkan untuk level $10 \%$ dan $30 \%$ masing waktu leleh berkisar 18 menit dan 22 menit hal ini dikarenakan kandungan susu pada level $10 \%$ persen masih tinggi sedangkan untuk level $30 \%$ kandungan kacang merahnya lebih tinggi. Hal ini sesuai dengan pendapat hidayah (2016) yang menyatakan bahwa kandungan lemak dan protein pada es krim dapat menhasilkan tekstur lembut dan memberikan sifat pelelehan yang baik pada es krim.

Berdasarkan hasil sidik ragam menunjukkan bahwa level penambahan kacang merah dengan perlakuan $10-30 \%$ berpengaruh sangat nyata $(P<0,01)$ terhadap nilai daya leleh es krim dibandingkan dengan tidak ditambahkan kacang merah. Hasil uji lanjut Duncan menunjukkan $\mathrm{K}_{2}$ berbedah nyata dengan $\mathrm{K}_{0}, \mathrm{~K}_{1}$, dan $\mathrm{K}$. Daya leleh adalah waktu yang dibutuhkan 
es krim untuk meleleh seluruhnya pada suhu ruang. Pengukuran daya leleh dilakukan pada suhu ruang. Kecepatan pelelehan ini sebagai salah satu parameter untuk mengetahui kualitas es krim (Syafarini, 2009).

\section{KESIMPULAN DAN SARAN}

\section{Kesimpulan}

Berdasarkan hasil penelitian disimpulkan bahwa persentase kacang merah (phaseoulus vulgaris $L)$ pada es krim berpengaruh sangat nyata $(P<0,01)$ terhadap karakteristik organoleptik meliputi rasa, aroma, warna, dan tekstur. Persentase kacang merah (Phaseoulus vulgaris $L$ ) yang paling baik digunakan dalam es krim yaitu persentase 30\%. Semakin tinggi presentase penambahan kacang merah (Phaseoulus vulgaris $L$ ) dalam pembuatan es krim, maka semakin rendah daya leleh es krim.

\section{Saran}

Penelitian menyarankan untuk dilakukan penelitian lanjutan menggunakan jenis susu yang berbeda dengan penambahan es krim kacang merah yang dikombinasikan dengan bahan aditif lainnnya.

\section{DAFTAR PUSTAKA}

Badan Standarisasi Nasional. 1995. Es Krim. SNI No. 6929:2016. Badan Standarisasi Nasional. Jakarta.

Direktorat Gizi Departemen Kesehatan RI., 1998, Daftar Komposisi Bahan Makanan, Jakarta

Lanusu, A., D. Surtijono, Karisoh, dan Sondakh. 2017. Sifat Organoleptik Es Krim Dengan Penambahan Uji Jalar Ungu (Ipomea batatas L). Jurnal Zootek ("Zootek” Journal). Vol. 37 No. $2: 474-482$.

Legowo, A., M. Kusrahayu, dan Mulyani, S. 2009. Ilmu dan Teknologi Susu.BP UNDIP Semarang.

Midayanto, D dan Yuwono, S. 2014. Penentuan Atribut Mutu Tekstur Tahu untuk Direkomendasikan sebagai Syarat Tambahan dalam Standar Nasional Indonesia. Jurnal Pangan dan Agroindustri, 2(4): 259-267.

Nurlita, Hermanto dan Asyik N. 2017. Pengaruh Penambahan Tepung Kacang Merah (Phaseolus vulgaris L) Dan Tepung Labu Kuning (Cucurbita moschata) terhadap Penilaian Organoleptik Dan Nilai Gizi Biskuit.

Nurwantoro. 2009. Bahan Ajar Dasar Teknologi Hasil Ternak. Fakultas Peternakan Universitas Diponegoro. Semarang

Padaga. 2005. Membuat Es Krim Yang Sehat. Trubus Agrisana. Surabaya. 
Syafarini, Isnaini. 2009. "Karakteristik Produk Tepung Es Krim dengan Penambahan Hidrokoloid Karaginan dan Alginat". (Skripsi S-1 Program Studi Teknologi Hasil Perikanan). Bogor: Fakultas Perikanan dan IImu Kelautan Institut Pertanian Bogor

Thompson, K. R., D. H. Chambers dan Anal E. Chambers. 2009. Sensory Characteristic of Ice Cream. Produced in The Unileal States and Italy. Published in Journal of Sensory Studies. 24: 394-414.

Uswatun, A. 2011. Kandungan Gizi dan Serat Pada Pembuatan Es Krim Kacang Merah. Skripsi. Universitas Negeri Yogyakarta. Yogyakarta.

Verawati. 2015. Pengaruh Substitusi Tepung Kacang Merah Terhadap Kualitas Kulit Pie. Skripsi. Universitas Negeri Padang. Padang.

Winarno, F. G. 2002. Kimia Pangan dan Gizi. PT. Gramedia Pustaka Utama. Jakarta. 